УДК 378.091.12.011.3-051

DOI:

Леся Смеречак, кандидат педагогічних наук, доцент кафедри соичільної педагогіки та корекиійної освіти Дрогобииького державного педагогічного університету імені Івана Франка

\title{
ОСОБЛИВОСТІ ПЕДАГОГІЧНОЇ ДІЯЛЬНОСТІ ВИКЛАДАЧА ВИЩОЇ ШКОЛИ
}

Автором здійснено спробу проаналізувати особливості педагогічної діяльності викладача педагогічного університету в сучасних умовах. Аргументовано, щуо викладач повинен забезпечити повний цүикл взаємодії “абітурієнт-студент-випускник” щзодо изінностей, норм, традицій випускової кафедри, факультету, закладу вищзої освіти.

На основі аналізу наукових розвідок сучасних досліджень виокремлено такі основні компоненти діяльності викладача педагогічного університету: гностичний, комунікативний, організаційний.

Ключові слова: педагог; заклад вищої освіти; структурні компоненти педагогічної діяльності.

Jim. 8.

Lesya Smerechak, Ph.D.(Pedagogy), Associate Professor of the Social Pedagogy and Correctional Education Drohobych Ivan Franko State Pedagogical University

\section{THE PECULIARITIES OF HIGH SCHOOL TEACHER'S PEDAGOGICAL ACTIVITIES}

The author has made an attempt to analize peculiarities of the high school teacher's pedagogical activities at nowadays conditions. It has been proved that the present state of the education quality is strengthened by growing demands of the society as to the level of the graduate's competences, his skills of making projects, of forecasting etc. It has been proved, that the high school teacher must provide the full cycle of interaction "an applicant - a student - a graduate" as to the values, norms, traditions of the chair, of the faculty, of the higher education establishment.

Based on the analysis of the present scientific investigations there have been established main components of the high school teacher's activities: gnostic, communicative, organizational. The indicators of formation of the gnostic component have been characterized, namely knowledge of: priority directions of modernization of higher educational system in Ukraine; the specifics of teaching activities at a pedagogical university; educational disciplines, special courses, etc.; the essence of the competent approach to the students' learning; the specifics of interactive learning technologies usage; the organizational peculiarities of research and educational work at the higher education establishment; means of influence on students; foreign language, etc.

The indicators of the communicative component formation have been viewed: a pedagogical tact, an ability to work with the team and in the team, to respect the opinion of others (both colleagues and students), to adequately perceive criticism; readiness for mutual assistance and mutual understanding, etc. It has been proved that the indicators of the organizational component formation should be considered as the ability to self-organization of the teacher's own pedagogical activities, as well as to the organization of the students' educational activities.

Keywords: pedagogue; higher educational establishment; structural components of pedagogical activities.

П остановка проблеми. Сучасний стан проблеми якості вищої освіти підсилюються зростаючими вимогами суспільства до рівня компетентності випускника, його здібностей до проектування, прогнозування тощо.

Вища освіта визначається сукупністю систематизованих знань, умінь і практичних навичок, способів мислення, професійних, світоглядних і громадянських якостей, моральноетичних цінностей, інших компетентностей, здобутих у закладі вищої освіти (науковій установі) у відповідній галузі знань за певною кваліфікацією на рівнях вищої освіти, що за складністю $є$ вищими, ніж рівень повної загальної середньої освіти та регламентується Законом України "Про вищу освіту”. Цей Закон встановлює основні правові, організаційні, фінансові засади функціонування системи вищої освіти, створює умови для посилення співпраці державних органів i бізнесу з закладами вищої освіти на принципах автономії закладів вищої освіти, поєднання освіти 3 наукою та виробництвом 3 метою підготовки конкурентоспроможного людського капіталу для високотехнологічного та інноваційного розвитку країни, самореалізації особистості, забезпечення потреб суспільства, ринку праці та держави у кваліфікованих фахівцях [8].

Серед різних факторів, що визначають якість та ефективність вищої освіти, найважливішою, без сумніву, є особистість викладача. Закон України "Про освіту" дає право викладачу бути академічно мобільним, однак, виникає питання: "У яких концептуальних категоріях описувати діяльність педагога вищої школи?”. 
Аналіз останніх досліджень і публікацій. Окремі аспекти професійної діяльності викладача вищої освіти висвітлюють В. Безрукова, І. Бопко, С. Вітвицька, О.Волобуєва, С. Горчинський, В. Гринько, О. Гунченко, К. Касярум, І. Княжева, Г. М'ясоїд, І. Олійник, В. Ортинський, Н.Скотна та ін.

Так, О. Гунченко розглядає проблеми формування іміджу викладача вищої школи, доводить, що в сучасних умовах імідж викладача вищої школи починає набувати властивості одного 3 основних ресурсів, що забезпечує як високий соціальний престиж і успішність функціонування національної системи вищої освіти в цілому, так і конкретного вищого навчального закладу, зокрема [3].

Сучасні дослідники В. Гринько [2], В. Ортинський [7], розкриваючи особливості педагогічної діяльності викладача вищої школи, конкретизують компоненти педагогічної діяльності. С. Горчинський розкриває особливості методичної діяльності в структурі педагогічної діяльності викладача закладу вищої освіти.

Сучасні вимоги до викладача вищої школи, тенденції світової педагогічної практики висвітлено у наукових розвідках К. Касярум, Г. М'ясоїд та ін.

Незважаючи на чималий інтерес дослідників до піднятої проблеми, серед науковців немає чіткого єдиного підходу до виокремлення компонентів педагогічної діяльності, що й зумовлює актуальність теми статті.

Мета статті - визначити структурні компоненти педагогічної діяльності викладача вищої школи.

Відповідно до поставленої мети, нами окреслено такі завдання:

1) проаналізувати особливості педагогічної діяльності викладача вищої школи;

2) охарактеризувати зміст структурних компонентів діяльності викладача в умовах закладу вищої освіти.

Виклад основного матеріалу. Розкриття даного питання має починатися 3 окреслення специфіки педагогічної діяльності, яку ми розуміємо як таку, що “вимагає від педагога грунтовної орієнтації у наукових засадах професії вчителя-вихователя, усвідомлення нових завдань школи, вміння розв'язувати їх швидко й на високому рівні. Вчителю доводиться постійно аналізувати педагогічний досвід, проводити власні експерименти, поповнювати та вдосконалювати свої знання" $[4,55]$.

Важливим є те, що професійні дії педагога вищої школи визначаються різноманітністю та динамічністю. Значна роль викладача у підвищенні якості освіти привертає увагу багатьох авторів. Сучасні дослідники (В. Безрукова, С. Вітвицька, С. Горчинський, В. Гринько, Н. Кузьміна, О. Власенко та ін.) вважають за доцільне виокремлювати такі основні структурні компоненти педагогічної діяльності викладача вищої школи: конструктивний, організаційний, управлінський, комунікативний, методичний, дослідницький, виховний, громадський.

Опираючись на ці дослідження, вважаємо за доцільне назвати такі основні компоненти діяльності викладача педагогічного університету: гностичний, комунікативний, організаційний.

Гностичний компонент включає знання:

- пріоритетних напрямів модернізації системи вищої освіти України;

- специфіки викладацької діяльності в умовах закладу вищої освіти;

- методики викладання;

- сутності компетентнісного підходу до навчання студентів;

- специфіки застосування інтерактивних технологій навчання;

- особливостей організації науководослідницької та виховної роботи узакладі вищої освіти;

- засобів впливу на студентів;

- іноземної мови тощо.

Нам імпонує наукова позиція Г. М'ясоїд, котра конкретизує вимоги до викладача вищої школи, до яких відносить: знання предмету, уміння виступати експертом із галузі знань, яку він викладає, дослідником, порадником, організатором і виконавцем навчального процесу, представником 3ВО перед громадою та установами, а також фасилітатором навчальної та дослідницької діяльності студентів, членом команди з розробки принципово нових курсів і дисциплін, які пропонуються для вибору студентам закладу вищої освіти, адміністратором, розробником навчальних проектів, менеджером і навіть фінансовим керівником проекту $[6,111]$.

Окрім іншого, викладач вищої школи повинен методично грамотно готуватися до лекційних занять, уміти доступно пояснювати навчальний матеріал; формувати інтерес до різних навчальних дисциплін; бути відповідальним за навчальні досягнення студентів та об'єктивність оцінювання тощо.

При цьому викладач має враховувати: суб'єктні характеристики студентів; активно використовувати інтерактивні технології навчання; вміти проектувати виховний вплив куратора академічної групи.

Комунікативний компонент. Педагогічна 


\section{ОСОБЛИВОСТІПЕДАГОГІЧНОЇ ДІЯЛЬНОСТІ ВИКЛАДАЧА ВИЩОЇ ШКОЛИ}

діяльність викладача закладу вищої освіти має двосторонній та взаємообумовлений характер професійної діяльності, так як, з одного боку, викладач працює зі студентами, а з іншого - в педагогічному колективі (кафедри, факультету, університету тощо). Це вимагає наявності у нього комунікативних якостей, а відтак - педагогічного такту, вміння працювати з колективом і в колективі, поважати думку інших (як колег, так і студентів), адекватно сприймати ділову критику, готовності до взаємодопомоги та взаєморозуміння тощо.

Педагог повинен так будувати заняття (як лекційні, так і семінарські), щоб студенти змогли успішно застосувати отримані знання на практиці, розвинути професійні здібності, розширити коло власного інформаційного простору.

Викладач вищої школи повинен розуміти значення і цінність комунікативних процесів у професійній діяльності, виявляти готовність до інтенсивної міжособистісної та групової комунікації зі студентами в різній формі: вербальній, невербальній, документній, електронній $[5,26]$.

Погоджуємося, що комунікативний компонент забезпечує встановлення контактів із студентами, колегами, адміністрацією, батьками тощо. Завдяки комунікативним здібностям викладач передає навчальну інформацію студентам, активізує їхню навчально-пізнавальну діяльність, налагоджує наукові контакти з іншими науковцями, висвітлює різні наукові положення, погляди, думки 3 досліджуваної наукової проблеми у власних публікаціях [2, 168].

Основними критеріями педагогічного професіоналізму сучасного викладача закладу вищої освіти (за О. Гунченко) постають: ділова ініціатива, інноваційність мислення, комунікативна компетентність, здатність викликати симпатію, здійснювати сприятливе враження і позитивно впливати на тих, хто оточує; створювати атмосферу психологічного комфорту та довіри $[3,80]$.

Комунікативна взаємодія, як педагогічний засіб, має бути спрямована на формування як ділових, так і тісних взаємин між педагогом і студентами. У педагогічній науці накопичений чималий досвід використання педагогічних технологій, спрямованих на саморозвиток особистості. Такий підхід дозволяє студентові (майбутньому фахівцеві) усвідомити соціальну значимість обраної професії, самореалізуватися, бути затребуваним як професіонал. Відповідно до сказаного, викладач має бути здатним не “формувати” студента відповідно до певних шаблонів, а допомогти йому “знайти себе”, своє професійне "Я“; навчити студента вчитися, а не лише накопичувати знання.

Вважаємо, що викладач має докладати максимум зусиль для виховання студентів, формування потреби в професійній самоідентифікації; створення атмосфери сприйняття конструктивної критики та швидкої реакції на неї, атмосфери постійного пошуку шляхів підвищення ефективності освітнього процесу; сприяння та розвитку інноваційності; активізації потребово-мотиваційної сфери.

Організаційний компонент. В умовах закладу вищої освіти діяльність викладача не обмежується лише викладанням окремих навчальних дисциплін. Вагомим показником ефективності професійної діяльності-є здатність як до самоорганізації власної педагогічної діяльності, так і до організації навчальної діяльності студентів.

У своєму дослідженні ми опираємося на класифікацію функцій педагогічної діяльності, поданої О. Волобуєвою:

1) управління - організація педагогічної діяльності;

2) виховання - формування в особистості необхідних поглядів на навколишню дійсність і життя в суспільстві;

3) навчання - формування знань, навиків і умінь із урахуванням вимог сучасної життєдіяльності;

4) розвиток - забезпечення функціональної доскональності розумової і фізичної діяльності особистості відповідно до вимог її діяльності та умов життя;

5) психологічна підготовка - формування в особистості внутрішньої готовності до подолання життєвих труднощів [1, 395].

Викладач повинен уміти налагоджувати зв’язки з контактними аудиторіями: абітурієнтами, роботодавцями, випускниками, органами загальнодержавної та місцевої влади тощо; бути толерантним у ставленні до інтелектуальної власності співробітників у сфері методичного забезпечення навчальних курсів; сприяти укріпленню академічних традицій закладу вищої освіти; документально оформляти нормативні, організаційні та методичні засади діяльності кафедри, факультету, ЗВО тощо.

У розрізі сказаного вище, актуальною є думка О. Гунченко, котра наголошує на тому, що викладач вищої школи є “"зразком високої культури, моралі, активним пропагандистом національних культурних традицій, патріотом власної справи та свого університету, який постійно піклується про створення безпечних умов навчально-виховного процесу, бо імідж викладача вищої школи, як взірця для наслідування студентами, формується 


\section{ОСОБЛИВОСТІПЕДАГОГІЧНОЇ ДІЯЛЬНОСТІ ВИКЛАДАЧА ВИЩОЇ ШКОЛИ}

поступово, охоплюючи як внутрішні так і зовнішні якості особистості" [3, 84].

Викладач має забезпечити повний цикл взаємодії “абітурієнт-студент-випускник” щодо цінностей, норм, традицій випускової кафедри, факультету, закладу вищої освіти. Важливим при цьому є створення умов для продукування нових ідей студентів, формування мобільних студентських груп, клубів за інтересами, наукових гуртків тощо. Окрім іншого, вагомого значення у роботі викладача набуває аналіз чинників соціалізації студента на мікро-, мезо- та макрорівнях; моніторинг та самоекспертиза освітнього середовища. У контексті сказаного набуває актуальності налагодження системи аудиторної та позааудиторної роботи; вироблення стратегії і тактики спільних дій професорськовикладацького колективу, спрямованих на оптимізацію освітнього процесу, створення умов для самореалізації студентів, пошук новітніх педагогічних технологій. Об'єктами дослідження в освітньому середовищі мають бути критерії оцінювання навчальних досягнень студентів, їхньої науково-дослідницької діяльності; потребово-мотиваційної сфери студентів, їхніх ціннісних орієнтацій; порогових рівнів оцінок за кожним видом діяльності, інтеграції освітнього та соціального середовищ; результатів проходження практики.

Вважаємо, що необхідним є удосконалення методичної складової практики студентів. Нагадаємо, методика розглядається як сукупність найбільш доцільних способів і засобів діяльності в умовах конкретного ресурсного середовища. Відтак, актуальним залишається питання щодо підвищення ролі методиста (як носія системних знань про різні види практики), сприяння співпраці викладача (методиста) 3 методичними кабінетами (центрами) тощо.

Висновки. На основі аналізу наукових розвідок сучасних досліджень, виокремлено основні компоненти діяльності викладача вищої школи: гностичний, комунікативний, організаційний. Успішна реалізація функцій викладача вищої школи можлива лише за умови сформованості усіх компонентів.

Перспективи подальших наукових розвідок вбачаємо в аналізі рівнів сформованості компонентів педагогічної діяльності викладача вищої школи.

\section{ЛІТЕРАТУРА}

1. Волобуєва О.Ф. Професійна діяльність сучасного викладача вищої школи: виклики та пріоритети / Олена Федорівна Волобуєва // Збірник наукових праць Національної академії Державної прикордонної служби України. Сер.: Педагогічні та психологічні науки. - 2014. - № 4. - С. 392 406.

2. Гринько В. О. Особливості педагогічної діяльності викладача вищої школи у сучасну епоху / В.О. Гринько. - [Електронний ресурс]: Джерело доступу: http://www.soc.univ.kiev.ua/sites/default/ files/library/elopen/actprob17_166.pdf

3. Гунченко О. Г Імідж викладача вищої школи / О. Г. Гунченко // Духовність особистості: методологія, теорія і практика. - 2014. - 4 (63). С. $79-85$.

4. Дубасенюк О.А. Методика викладання педагогіки: навчальний посібник: Вид. 2-ге, доп. / Дубасенюк О.А., Антонова О.Є. - Житомир: Видво ЖДУ ім. І. Франка, 2012. - 375 с.

5. Касярум К.В. Комунікативна компетентність викладача вищої школи / К.В. Касярум // Наукова скарбниця освіти Донеччини. - 2013. - № 2 (15). C. $24-27$.

6. М'ясоїд Г. І. Сучасні вимоги до викладача вищої школи: огляд тенденцій світової педагогічної практики / Г. І. М'ясоїд // Педагогічні науки: теорія, історія, інноваційні технології. - 2015. - № 3 (47). - C. 107-113.

7. Ортинський В. Л. Педагогіка вищої школи: навч. посіб. [для студ. вищ. навч. закл.]/В.Л. Ортинський/ - К.: Центр учбової літератури, 2009. - 472 с.

8. Рівні вищої освіти та наукові ступені [Електронний ресурс]: Джерело доступу: https:// mon.gov.ua/ua/osvita/visha-osvita/rivni-vishoyi-osvitita-naukovi-stupeni

\section{REFERENCES}

1. Volobuieva, O. F. (2014). Profesiina diialnist suchasnoho vykladacha vyshchoi shkoly: vyklyky ta priorytety [A professional diyalnist suchasnoho vykladacha vyshchoi shkoly: vyklyky that priorytety]. Journal of the National Academy of the State Border Guard Service of Ukraine. Vol. 4, pp. 392 406. [in Ukrainian].

2. Hrynko, V. O. (2017). Osoblyvosti pedahohichnoi diialnosti vykladacha vyshchoi shkoly u suchasnu epokhu [Features of pedagogical activity of the teacher of higher education in the modern era]. [Electronic resource]. Available at: http:// www.soc.univ.kiev.ua/sites/default/files/library/ elopen/actprob17 166.pdf [in Ukrainian].

3. Hunchenko, O. H. (2014). Imidzh vykladacha vyshchoi shkoly [The image of a high school teacher]. Personality spirituality: methodology, theory and practice. Vol. 4 (63). pp. 79 - 85. [in Ukrainian].

4. Dubaseniuk, O. A. \& Antonova, O. I. (2012). Metodyka vykladannia pedahohiky: Navchalnyi 


\section{ФОРТЕПІАННА АНСАМБЛЕВА МУЗИКА МИРОСЛАВАСКОРИКА В РЕПЕРТУАРІ ЛЬВІВСЬКИХ ДУЕТІВ ПІАНІСТІВ}

posibnyk: Vyd. 2-he, dop. [Methodology for the study of pedagogy]. Zhytomyr Ivan Franko State University, 375 p. [in Ukrainian].

5. Kasiarum, K. V. (2013). Komunikatyvna kompetentnist vykladacha vyshchoi shkoly [The communicative competence of the teacher of higher education]. Scientific treasury of education of Donetsk region. Vol. 2 (15), pp. 24 - 27. [in Ukrainian].

6. Miasoid, H. I. (2015). Suchasni vymohy do vykladacha vyshchoi shkoly: ohliad tendentsii svitovoi pedahohichnoi praktyky [Modern requirements for a teacher of higher education: an overview of trends in world pedagogical practice]. Journal of the Pedagogical sciences: theory, history, innovative technologies. Vol. 3 (47), pp. 107-113. [in Ukrainian].

7. Ortynskyi, V. L. (2009). Pedahohika vyshchoi shkoly: navch. posib. [Pedagogy of higher education: teaching. manual]. Kyiv: Tsentr uchbovoi literatury, 472 p. [in Ukrainian]

8. Rivni vyshchoi osvity ta naukovi stupeni [Levels of higher education and academic degrees]. [Electronic resource]. Available at: https:// mon.gov.ua/ua/osvita/visha-osvita/rivni-vishoyi-osvitita-naukovi-stupeni [in Ukrainian].

Стаття надійшла до редакції 29.10.2018

УДК 78.071.1(477)

DOI:

Уляна Молчко, доцент кафедри музикознавства та фортепіано навчально-наукового інституту музичного мистеитва Дрогобищького державного педагогічного університету імені Івана Франка Ірина Стецівка, студентка магістратури навчально-наукового інституту музичного мистецтва Дрогобищького державного педагогічного університету імені Івана Франка

\section{ФОРТЕПАННА АНСАМБЛЕВА МУЗИКА МИРОСЛАВА СКОРИКА В РЕПЕРТУАРІ ЛЬВІВСЬКИХ ДУЕТІВ ПІАНІСТІВ}

У статті розглядається фортепіанна ансамблева музика Мирослава Скорика, яка впродовж двадчяти років зайняла провідне місие на концеертній естраді як в Украйні, так $i$ за кордоном. Здійснено аналіз стилістичних особливостей, технічно-виконавських засад творів для дуету. Характеризуючи проблеми інтерпретаиії творів для колективного музикування, автори опираються на багаторічний мистецький досвід сучасних львівських піаністів, а саме Оксани Рапіти та Мирослава Драгана, а також Олександри Німилович та Уляни Молчко.

Ключові слова: М. Скорик; фортепіанний ансамбль; інтерпретація; джсазова стилістика; технічновиконавські особливості.

Jim. 7.

Ulyana Molchko, Associate Professor of the Musicology and Piano Department Educational and Scientific Institute of Musical Art Drohobych Ivan Franko State Pedagogical University Iryna Stetsivka, Student of the Educational and Scientific Institute of Musical Art Drohobych Ivan Franko State Pedagogical University

\section{PIANO ENSEMBLE MUSIC BY MYROSLAV SKORYC IN THE REPERTOIRE OF LVIV PIANISTS DUES}

The piano ensemble music by Myroslav Skoryk, which has occupied for twenty years a leading place on the concert stage both in Ukraine and abroad is considered in this article. On July 13, 2018 as the founder of contemporary Ukrainian music, People's Artist of Ukraine, the winner of the National Prize of Ukraine named after T. Shevchenko, Hero of Ukraine - Myroslav Skoryk turned 80 years old. The entire cultural and educational community, honoring this jubilee, held a series of concerts in Kyiv, Kharkiv, Lviv and other cities. Among the voluminous versatile composition by a composer M. Skoryk stands up his piano ensemble music. The works for the duet have long been firmly included in the repertoire of Ukrainian pianists. One of their first interpreters was M. Scoryk himself and V. Vynnytskiy.

Analyzing the stylistic peculiarities, technical and performing principles of the works for M. Skoryk's duet, their textual convenience, precise alignment of registers, juicy colorism and piano virtuosity were noted. But the most important thing in ensemble pieces is the energetic fullness, sincerity of the statement, high spirituality and 